\title{
PROFITABILITAS, PERTUMBUHAN PERUSAHAAN DAN UKURAN PERUSAHAAN SEBAGAI DETERMINAN STRUKTUR MODAL
}

\author{
Wayan Wardita* Made Purba Astakoni \\ STIMI "Handayani", Denpasar, Bali \\ *E-Mail: warditayanwar@gmail.com
}

Halaman: 20 - 32

\begin{abstract}
Abstrct
The purpose of this research is; analyze and explain the effect of profitability on the capital structure, analyze and explain the effect of growth rate (growth) on capital structure, analyze and explain the effect of profitability to the wide company at PT. Mustika Ratu and Subsidiaries. In this research data analysis technique using Partial Least Square (PLS) approach. PLS is a model of Structural Equation Modeling (SEM) equations based on components or variants. Based on hypothesis testing found that profitability have a significant negative effect on capital structure at PT. Mustika Ratu and Subsidiaries. This is indicated by the value of coefficient of -0.20860009 with the value of t-statistics of 14.465286 above the critical value of 1.96 , so it shows that the higher the profitability of a company will lower the value of the company's capital structure. Growth rate (growth) has a significant negative effect on capital structure at PT. Mustika Ratu and Subsidiaries. This shows that the higher the company's growth will decrease the value of the company's capital structure. This is indicated by the coefficient value of -0.300925 with a t-statistic value of 20.32658 above the critical value of 1.96 , so this indicates that the higher growth rate (a company) will lower the value of the company's capital structure, and firm size (size) have a significant positive effect on capital structure at PT. Mustika Ratu and Subsidiaries. This shows that the higher the size (size) of a company will increase the company's capital structure. This condition is shown by the coefficient value of 0.660465 with the value of t-statistics of 29.89193 (larger 1.96).
\end{abstract}

Keywords: capital structure. profitability, corporate growth, company zize

\begin{abstract}
Abstrak
Tujuan penelitian ini adalah; menganalisis dan menjelaskan pengaruh profitabilitas terhadap struktur modal, menganalisis dan menjelaskan pengaruh tingkat pertumbuhan (growth) terhadap struktur modal, menganalisis dan menjelaskan pengaruh profitabilitas terhadap luas perusahaan pada PT. Mustika Ratu dan Entitas Anak. Dalam penelitian ini teknik analisis data menggunakan pendekatan Partial Least Square (PLS). PLS adalah model persamaan Structural Equation Modeling (SEM) yang berbasis komponen atau varian. Berdasarkan pengujian hipotesis didapatkan bahwa profitabilitas berpengaruh negatif signifikan terhadap struktur modal pada PT. Mustika Ratu dan Entitas Anak. Hal ini ditunjukkan oleh nilai koefisien sebesar -0,20860009 dengan nilai t-statistik sebesar 14,465286 diatas nilai kritis 1,96, sehingga hal ini menunjukkan bahwa semakin tinggi nilai profitabilitas (profitability) suatu perusahaan maka akan menurunkan nilai struktur modal perusahaan tersebut. Tingkat pertumbuhan (growth) berpengaruh negatif signifikan terhadap struktur modal pada PT. Mustika Ratu dan Entitas Anak. Hal ini menunjukkan bahwa semakin tinggi pertumbuhan perusahaan maka akan menurunkan nilai struktur modal perusahaan tersebut. Hal ini ditunjukkan oleh nilai koefisien sebesar 0,300925 dengan nilai t-statistik sebesar 20,32658 diatas nilai kritis 1,96, sehingga hal ini menunjukkan bahwa semakin tinggi tingkat pertumbuhan (growth) suatu perusahaan maka akan menurunkan nilai struktur modal perusahaan tersebut, dan ukuran perusahaan (size) berpengaruh positif signifikan terhadap struktur modal pada PT. Mustika Ratu dan Entitas Anak. Hal ini menunjukkan bahwa semakin tinggi ukuran (size) suatu perusahaan maka akan meningkatkan struktur modal perusahaan tersebut. Kondisi ini ditunjukkan oleh nilai koefisien sebesar 0,660465 dengan nilai t-statistics sebesar 29,89193 (lebih besar 1,96).
\end{abstract}

Kata Kunci : struktur modal. profitabilitas, pertumbuhan perusahaan, ukuran perusahaan 


\section{PENDAHULUAN}

Ada ungkapan umum yang menjadi filosofi dalam manajemen keuangan modern, khususnya mengenai struktur modal, yakni borrow as much as you can get and don't spread your earning but spread your risk, kedua ungkapan ini memberikan nasehat kepada investor atau perusahaan agar bijak dalam menentukan komposisi struktur modal pilihan pendanaannya. Hutang sebagai sumber pendanaan eksternal menjadi sesuatu yang menarik bagi perusahaan untuk rekapitalisasi atau restrukturisasi modal dan pengembangan operasi bisnisnya disamping modal sendiri. Dalam konteks manajemen keuangan hutang bermanfaat karena memberikan financial leverage yang dapat meningkatkan pendapatan per lembar saham. Namun hutang yang terlalu besar akan menambah risiko keuangan dan dapat menimbulkan cost of financial distress (Lumbantobing, 2008).

Perusahaan sebagai suatu entitas yang beroperasi dengan menerapkan prinsip-prinsip ekonomi, umumnya tidak hanya berorientasi pada pencapaian laba maksimal, tetapi juga berusaha meningkatkan nilai perusahaan dan kemakmuran pemiliknya. Oleh karena itu, perusahaan memiliki rencana strategis dalam rangka pencapaian tujuan yang telah ditetapkan. Manajer keuangan harus mampu menghimpun dana yang bersumber dari internal maupun eksternal perusahaan secara efisien, dalam arti keputusan pendanaan tersebut merupakan keputusan pendanaan yang mampu meminimalisasikan biaya modal (cost of capital) yang ditanggung perusahaan. Suatu perusahaan dalam permulaan usahanya akan memenuhi kebutuhan dananya dengan mengutamakan pemenuhan sumber dari internal, sehingga dapat mengurangi ketergantungan kepada pihak luar. Sesaat setelah usaha yang dijalankan ini berkembang, perusahaan dituntut untuk mencari alternatif pendanaan dari sumber yang lain, dan dalam hal ini dari luar perusahaan (sumber eksternal). Perusahaan dalam menggunakan sumber eksternal akan terlebih dahulu memilih menggunakan hutang, baik itu jangka pendek, ataupun jangka panjang sebelum menerbitkan saham. Hal ini sesuai dengan Pecking Order Theory yang dikemukakan oleh Myers dan Majluf (1984) ( dalam Kusuma \& Arifin, 2012). Pecking Order Theory (POT) menyatakan bahwa "penentuan sumber modal yang optimal didasarkan pada keputusan pendanaan secara hierarki berdasarkan biaya modal yang paling murah yang bersumber pada sumber dana internal (profit) sampai pada sumber dana eksternal (hutang dan saham)".

Struktur modal terkait erat dengan struktur keuangan, menurut (Brigham \& Houston, 2011) "Struktur keuangan adalah cara bagaimana perusahaan membiayai aktivanya. Struktur keuangan dapat dilihat pada sisi kanan neraca yang terdiri dari hutang jangka pendek, hutang jangka panjang dan modal pemegang saham. Jadi, struktur modal suatu perusahaan hanya merupakan sebagian dari struktur keuangannya". Didalam menentukan struktur modal yang optimal, ada beberapa faktor mikro perusahaan yang dapat mempengaruhinya, seperti ukuran perusahaan, profitabilitas, likuiditas dan sebagainya. Lebih lanjut (Brigham \& Houston, 2011) menunjukkan faktor-faktor yang umumnya dipertimbangkan oleh perusahaan ketika mengambil keputusan tentang struktur modal adalah; stabilitas penjualan,struktur aktiva, leverage operasi, tingkat pertumbuhan, profitabilitas, pajak, pengendalian, sikap manajemen, sikap pemberi pinjaman dan lembaga penilai peringkat, kondisi pasar, kondisi internal perusahaan, fleksibelitas keuangan. Kusuma \& Arifin, (2012), Mas'ud, (2008) menyatakan bahwa variabel-variabel yang mempengaruhi struktur modal adalah: (1) tingkat pertumbuhan penjualan (sales growth); (2) debt ratio; (3) profitability; (4) besarnya suatu perusahaan (firm size); (5) struktur aktiva (asset structure); (6) cost of financial distress.Ketika manajer menggunakan hutang, jelas biaya modal yang timbul sebesar bunga yang dibebankan oleh kreditor, sedangkan apabila manajer menggunakan dana internal akan timbul opportunity cost dari dana atau modal sendiri yang digunakan. Pada saat itu perusahaan akan membuat pertimbangan mengenai komposisi modal yang optimal, dan pertimbangan tersebut akan menghasilkan sebuah keputusan struktur modal atau keputusan pendanaan. Keputusan struktur modal merupakan keputusan keuangan yang berkaitan dengan kombinasi hutang dan ekuitas dalam struktur keuangan jangka panjang perusahaan.

Struktur modal merupakan masalah yang penting bagi perusahaan karena baik buruknya struktur modal akan mempunyai efek langsung terhadap posisi finansial perusahaan, yang pada akhirnya akan mempengaruhi nilai perusahaan. Kesalahan dalam menentukan struktur modal akan berdampak luas terutama apabila perusahaan terlalu besar dalam menggunakan hutang, sehingga beban tetap yang harus ditanggung perusahaan semakin besar pula. Hal ini juga berarti akan meningkatkan risiko finansial, yaitu risiko saat perusahaan tidak dapat membayar beban bunga atau angsuran-angsuran hutangnya. Struktur modal yang optimal dapat meminimumkan biaya modal rata-rata (average cost of capital) dan memaksimumkan nilai perusahaan. Oleh karena itu, agar kondisi tersebut dapat tercapai, maka perlu dipertimbangkan variabel-variabel yang mempengaruhi struktur modal.

Profitabilitas menunjukkan kemampuan perusahaan dalam memperoleh laba. Perusahaan yang memiliki profitabilitas besar tiap tahunnya cenderung diminati oleh investor. Para investor ini menganggap perusahaan yang profitnya besar akan menghasilkan return yang besar. Perusahaan yang memiliki tingkat profitabilitas tinggi tiap tahunnya memiliki kecenderungan untuk menggunakan modal 
sendiri dibanding dengan menggunakan hutang, hal ini sesuai apa yang dikatakan oleh Brigham dan Houston (2011) bahwa "tingkat pengembalian yang tinggi memungkinkan perusahaan-perusahaan tersebut melakukan sebagian besar pendanaannya melalui dana yang dihasilkan secara internal". Perusahaan yang memiliki tingkat profitabilitas yang tinggi setiap tahunnya, memiliki kecenderungan untuk menggunakan modal sendiri dibandingkan dengan menggunakan hutang (Kusuma \& Arifin, 2012). Asumsi lain juga menyebutkan dengan return on assets yang tinggi, yang berarti bahwa laba bersih yang dimiliki perusahaan tinggi. Oleh karena itu, apabila perusahaan menggunakan hutang yang besar, tidak akan berpengaruh terhadap struktur modal, karena kemampuan perusahaan dalam membayar bunga juga tetap tinggi

Tingkat pertumbuhan (growth) pada dasarnya mencerminkan produktivitas perusahaan dan merupakan suatu harapan yang diinginkan oleh pihak internal (manajemen) maupun pihak eksternal (investor dan kreditor) perusahaan. Beberapa peneliti seperti (Elim \& Yusfarita, 2010), Mas'ud (2008) mengemukakan bahwa pertumbuhan penjualan (sales growth) suatu perusahaan memiliki pengaruh terhadap struktur modal. Khusus mengenai ukuran perusahaan, Moeldjadi, (2006) berpendapat bahwa "suatu perusahaan yang berukuran besar lebih mudah memperoleh pinjaman jika dibandingkan dengan perusahaan kecil", akan tetapi, perusahaan besar seringkali mampu membiayai kegiatan operasional mereka sendiri dengan sumber internal daripada sumber eksternal, hal ini dikarenakan perusahaan besar memiliki pendapatan yang juga besar dibandingkan dengan perusahaan kecil, sehingga tidak perlu bergantung pada sumber pendanaan eksternal. Besar kecilnya perusahaan sangat tergantung pada struktur modal, terutama berkaitan dengan kemampuan memperoleh pinjaman. Perusahaan besar lebih mudah memperoleh pinjaman, sehingga mereka akan cenderung untuk berhutang karena kemungkinan mengalami risiko kebangkrutan yang rendah, disamping itu perusahaan yang besar dimana sahamnya tersebar sangat luas akan lebih berani mengeluarkan saham baru dalam memenuhi kebutuhannya untuk membiayai pertumbuhan penjualan dibandingkan dengan perusahaan yang kecil" (Riyanto, 2010) Namun disisi lain, berdasarkan pecking order theory, perusahaan yang besar akan cenderung menggunakan hutang relatif sedikit dibanding perusahaan kecil

Selain itu faktor yang dapat menentukan besarnya struktur modal adalah ukuran perusahaan (firm size). Ukuran perusahaan dianggap mampu mempengaruhi struktur modal,karena semakin besar ukuran atau skala perusahaan maka akan semakin mudah pula perusahaan memperoleh sumber pendanaan baik yang bersifat internal maupun eksternal. Ukuran perusahaan merupakan hal yang penting dalam proses pelaporan keuangan. Ukuran perusahaan dalam penelitian dapat dilihat dengan menghitung seberapa besar aset yang dimiliki oleh sebuah perusahaan. Aset yang dimiliki perusahaan ini menggambarkan hak dan kewajiban serta permodalan perusahaan. Perusahaan yang besar juga memiliki kecenderungan untuk menggunakan sumber pendanaan eksternal dari pada perusahaan kecil karena accessibility perusahaan ke pasar modal. Oleh karena itu, dapat disimpulkan semakin tinggi ukuran perusahaan maka struktur modal akan semakin tinggi. Begitu pula sebaliknya semakin kecil ukuran perusahaan maka semakin kecil pula struktur modalnya. Menurut Prabansari \& Kusuma, (2005) menyatakan bahwa dalam suatu perusahaan apabila semakin tinggi pertumbuhan penjualan maka akan lebih aman perusahaan menggunakan hutang sehingga akan semakin tinggi struktur modalnya. Bagi perusahaan dengan tingkat pertumbuhan penjualan dan labayang tinggi kecenderungan penggunaan utang sebagai sumber dana ekternal yng lebih besar dibandingkan dengan perusahaan yang mempunyai tingkat pertumbuhan penjualannya tergolong rendah. Sehingga struktur modal perusahaan menjadi besar. Menurut (Seftianne \& Ratih, 2011), menyatakan bahwa penentuan besar kecilnya skala perusahaan dapat ditentukan berdasarkan total penjualan, total aktiva, rata-rata tingkat penjualan dan rata-rata total aktiva.Perusahaan yang besar juga memiliki kecenderungan untuk menggunakan sumber pendanaan eksternal dari pada perusahaan kecil karena accessibility perusahaan ke pasar modal. Oleh karena itu, dapat disimpulkan semakin tinggi ukuran perusahaan maka struktur modal akan semakin tinggi. Begitu pula sebaliknya semakin kecil ukuran perusahaan maka semakin kecil pula struktur modalnya

Penelitian mengenai struktur modal bertujuan untuk menentukan model atau teori struktur modal yang dapat menjelaskan perilaku keputusan pendanaan perusahaan. Meskipun secara teori, faktor -faktor yang mempengaruhi keputusan struktur modal sulit diukur, namun berbagai penelitian empiris yang bertujuan untuk mengidentifikasi faktor-faktor yang mempengaruhi keputusan pendanaan perusahaan telah banyak dilakukan. Hasil penelitian (Agha, 2015) menemukan Variabel independen termasuk likuiditas, profitabilitas memiliki dampak signifikan dan berhubungan negatif dengan rasio hutang, yang berarti jika variabel-variabel ini meningkatkan rasio hutang akan turun. Variabel lain termasuk pajak dan pertumbuhan juga memiliki dampak signifikan dan hubungan positif yang berarti jika kedua variabel meningkat, rasio hutang akan naik. Penelitian (Rahmatillah \& Prasetyo, 2016) menunjukkan faktor paling signifikan yang mempengaruhi struktur modal seperti ukuran, tangibility, likuiditas, risiko, tingkat suku bunga, PDB dan kepemilikan. Temuan 
(Karadeniz, Kandır, Iskenderoglu, \& Onal, 2011) di Turki mengungkapkan bahwa ukuran perusahaan adalah faktor signifikan untuk keputusan struktur modal perusahaan penginapan Turki. Ukuran perusahaan nampaknya mempengaruhi perusahaan penginapan dalam menggunakan insentif, mengeluarkan saham biasa, menggunakan hutang pribadi dan menentukan target debt ratio. Sebagian besar temuan empiris nampaknya mendukung teori pecking order.

Berdasarkan paparan teori dan temuan empiris sebelumnya maka dalam studi ini yang menjadi tujuan adalah sebagai berikut ; (1) Menganalisis dan menjelaskan pengaruh profitabilitas (profitability) terhadap struktur modal pada PT. Mustika.Ratu dan Entitas Anak.(2)Menganalisis dan menjelaskan pengaruh tingkat pertumbuhan (growth) terhadap struktur modal PT. Mustika.Ratu dan Entitas Anak (3)Menganalisis dan menjelaskan pengaruh profitabilitas (profitability) terhadap luas perusahaan pada PT. Mustika.Ratu dan Entitas Anak

\section{TINJAUAN PUSTAKA}

\section{A. Tinjauan Pustaka}

\section{Struktur Modal}

Struktur modal adalah perimbangan atau perbandingan antara jumlah hutang jangka panjang dengan modal sendiri (Riyanto, 2010). Pendapat lain mengatakan bahwa struktur modal merupakan perimbangan jumlah hutang jangka pendek yang bersifat permanen, hutang jangka panjang, saham preferen, dan saham biasa (Sartono, 2010) Berdasarkan beberapa pendapat tersebut, pada dasarnya struktur modal yaitu pembiayaan perusahaan yang bersifat permanen yang terdiri dari hutang jangka panjang, saham biasa dan saham preferen."Struktur modal adalah pembelanjaan permanen dimana mencerminkan perimbangan antara hutang jangka panjang dengan modal sendiri" (Riyanto, 2010). Brigham dan Houston (2011) mengatakan struktur modal yang optimal dapat didefinisikan sebagai "struktur yang akan memaksimalkan harga saham perusahaan tersebut". Struktur modal yang baik dan optimal adalah struktur modal yang dapat meminimumkan biaya dan menyeimbangkan risiko dengan tingkat pengembalian. Hal ini didukung oleh pendapat (Husnan \& Pudjiastuti, 2010), yang menyatakan bahwa "struktur modal yang dapat memaksimumkan nilai perusahaan atau harga saham adalah struktur modal yang terbaik". Struktur modal erat kaitannya dengan harga saham, ini dikarenakan salah satu unsur yang membentuk harga saham adalah.

persepsi investor atas kinerja perusahaan, dan struktur modal adalah salah satu unsur yang menentukan baik buruknya kinerja perusahaan. Struktur modal adalah pencerminan dari perimbangan antara hutang jangka panjang dan modal sendiri dari suatu perusahaan. Perbaikan struktur permodalan dunia usaha merupakan keharusan untuk meningkatkan efisiensi dan memperkokoh daya saing perusahaan dalam menghadapi persaingan yang semakin tajam terutama dalam era globalisasi Struktur modal yang optimal adalah struktur modal yang dapat meminimumkan biaya dan mengoptimalkan keseimbangan antara risiko dan pengembalian, sehingga memaksimumkan harga saham. Struktur modal erat kaitannya dengan harga saham, hal ini dikarenakan salah satu unsur yang membentuk harga saham adalah persepsi investor atas kinerja perusahaan, dan struktur modal adalah salah satu unsur yang menentukan baik buruknya kinerja perusahaan, karena struktur modal akan menentukan sumber pembiayaan dan pembelanjaan yang dilakukan oleh manajer keuangan adalah berkaitan dengan komposisi struktur modal yang dapat meningkatkan nilai perusahaan. Perusahaan akan berusaha mencapai suatu tingkat struktur modal yang optimal dengan risiko yang paling kecil dengan memaksimalkan nilai perusahaan. Nilai perusahaan sendiri dapat diartikan sebagai harga yang bersedia dibayar oleh calon pembeli apabila perusahaan tersebut dijual. Nilai perusahaan merupakan ukuran keberhasilan manajemen perusahaan dalam operasi masa lalu dan prospek dimasa yang akan datang untuk meyakinkan pemegang saham yang diindikatori oleh rasio-rasio seperti market book value dan price earning ratio (PER) (Mas'ud, 2008).

\section{Profitabilitas (Profitability)}

Profitabilitas mengambarkan kemampuan perusahaan dalam memperoleh laba. Profitabilitas adalah hasil akhir dari sejumlah kebijakan dan keputusan yang dilakukan oleh perusahaan (Brigham \& Houston, 2011).Profitabilitas sering juga disebut Rentabilitas yang berarti kemampuan suatu perusahaan untuk mendapatkan laba selama periode tertentu.Profitabilitas (profitability) adalah kemampuan perusahaan memperoleh laba melalui operasional usahanya dengan menggunakan dana aset yang dimiliki oleh perusahaan. Pengertian lain juga menyebutkan bahwa profitabilitas (profitability) menunjukkan kemampuan perusahaan untuk menghasilkan keuntungan dan mengukur tingkat efisiensi operasional dan efisiensi dalam menggunakan harta yang dimilikinya. Perusahaan yang memiliki tingkat profitabilitas yang tinggi setiap tahunnya, memiliki kecenderungan untuk menggunakan modal sendiri dibandingkan dengan menggunakan hutang (Kusuma \& Arifin, 2012). Asumsi lain juga menyebutkan dengan return on assets yang tinggi, yang berarti bahwa laba bersih yang dimiliki perusahaan tinggi. Oleh karena itu, apabila perusahaan menggunakan hutang yang besar, tidak akan berpengaruh terhadap struktur modal, karena kemampuan perusahaan dalam membayar 
bunga juga tetap tinggi. Menurut (Brigham, EF., 2006) ukuran yang bisa mewakili profitabilitas diantaranya Return on Asset (ROA), Return on Equity (ROE), Operating Profit Margin (OPM) on Sales dan Basic Earning Power (BEP). Rasio-rasio profitabilitas tersebut menunjukkan hubungan antara dua data keuangan. Analisis dan penafsiran berbagai rasio akan memberikan pemahaman yang lebih baik terhadap kinerja dan kondisi perusahaan. Pengukuran profitabilitas dalam penelitian ini diukur menggunakan Return On Asset (ROA), Return On Equity (ROE) dan Operating Profit Margin (OPM). ROA merupakan rasio pengukuran yang menggambarkan seberapa besar pendapatan yang dihasilkan perusahaan dalam setiap rupiah yang ditanamkan dalam bentuk aset, ROE merupakan rasio pengukuran yang menunjukkan seberapa besar pendapatan yang diterima bagi pemegang saham terhadap investasi yang ditanamkan dan OPM merupakan rasio yang menunjukkan tinggi rendahnya kemampuan perusahaan untuk menghasilkan laba bersih terhadap penjualannya (Syamsuddin, 2004).

\section{Tingkat Pertumbuhan (Growth)}

Tingkat pertumbuhan (growth) pada dasarnya mencerminkan produktivitas perusahaan dan merupakan suatu harapan yang diinginkan oleh pihak internal (manajemen) maupun pihak eksternal (investor dan kreditor) perusahaan. Beberapa peneliti seperti Elim \& Yusfarita, (2010), Mas'ud (2008) mengemukakan bahwa pertumbuhan penjualan (sales growth) suatu perusahaan memiliki pengaruh terhadap struktur modal. Pengukuran tingkat pertumbuhan,Growth dalam penelitian ini diukur dengan menggunakan indikator pertumbuhan aktiva (assets growth) dan pertumbuhan penjualan (sales growth). Pertumbuhan aktiva (assets growth) menggambarkan kenaikan atau penurunan aktiva setiap tahun, sedangkan pertumbuhan penjualan (sales growth) menggambarkan kenaikan atau penurunan penjualan setiap tahun.

\section{Ukuran peusahaan (size)}

Ukuran peusahaan (size) merupakan suatu indikator yang menunjukkan kekuatan finansial perusahaan. Ukuran perusahaan dianggap mampu mempengaruhi nilai perusahaan, karena semakin besar ukuran atau skala perusahaan maka akan semakin mudah pula perusahaan memperoleh sumber pendanaan baik yang bersifat internal maupun eksternal. Besar kecilnya perusahaan sangat tergantung pada struktur modal, terutama berkaitan dengan kemampuan memperoleh pinjaman. Perusahaan besar lebih mudah memperoleh pinjaman, sehingga mereka akan cenderung untuk berhutang karena kemungkinan mengalami risiko kebangkrutan yang rendah, disamping itu perusahaan yang besar dimana sahamnya tersebar sangat luas akan lebih berani mengeluarkan saham baru dalam memenuhi kebutuhannya untuk membiayai pertumbuhan penjualan dibandingkan dengan perusahaan yang kecil" (Riyanto, 2010) Menurut (Ghozali, 2009) di dalam mengukur besar kecilnya suatu perusahaan, selain dapat menggunakan indikator net sales seperti yang digunakan Seftianne \& Ratih, (2011).Menurut (Seftianne \& Ratih, 2011), menyatakan bahwa penentuan besar kecilnya skala perusahaan dapat ditentukan berdasarkan total penjualan, total aktiva, rata-rata tingkat penjualan dan rata-rata total aktiva.Perusahaan yang besar juga memiliki kecenderungan untuk menggunakan sumber pendanaan eksternal dari pada perusahaan kecil karena accessibility perusahaan ke pasar modal. Oleh karena itu, dapat disimpulkan semakin tinggi ukuran perusahaan maka struktur modal akan semakin tinggi. Begitu pula sebaliknya semakin kecil ukuran perusahaan maka semakin kecil pula struktur modalnya.

\section{B. Hipotesis}

\section{Pengaruh Profitabilitas Terhadap Struktur Modal}

Profitabilitas adalah kemampuan perusahaan memperoleh laba dalam hubungannya dengan penjualan, total aktiva maupun modal sendiri (Sartono, 2010). Definisi lain menurut Mai, (2006) profitabilitas merupakan kemampuan peruahaan untuk memperoleh laba. Perusahaan-perusahaan dengan profit yang tinggi cenderung menggunakan lebih banyak pin- jaman untuk memperoleh manfaat pajak. Hal ini karena pengurangan laba oleh bunga pin- jaman akan lebih kecil dibandingkan apabila perusahaan menggunakan modal yang tidak dikenai bunga, namun penghasilan kena pajak akan lebih tinggi Mai, (2006).Keputusan pendanaan yang dilakukan secara tidak cermat akan menimbulkan biaya tetap dalam bentuk biaya modal yang tinggi, yang selanjutnya dapat berakibat pada rendahnya profitabilitas perusahaan (Kartini \& Tulus, 2008) . Jadi dengan kata lain, keputusan pendanaan atau struktur modal sangat berpengaruh terhadap rendah atau tingginya profitabilitas suatu perusahaan. Menurut pecking order theory, perusahaan dengan tingkat keuntungan yang besar memiliki sumber pendanaan internal yang lebih besar dan memiliki kebutuhan untuk melakukan pembiayaan investasi melalui pendanaan eksternal yang lebih kecil (Schoubben, F. \& Van Hulle, 2004) dan juga (Adrianto \& Wibowo, 2007). Dengan demikian, teori ini memprediksikan profitabilitas berpengaruh negatif terhadap struktur modal. Berdasarkan pernyataan tersebut, maka dapat dirumuskan hipotesis sebagai berikut.

H1: Profitabilitas berpengaruh negatif terhadap struktur modal. 


\section{Pengaruh Tingkat Pertumbuhan (Growth) Terhadap Struktur Modal}

Perusahaan dengan tingkat pertumbuhan yang tinggi, memerlukan dana yang lebih besar untuk membiayai operasinya. Sumber pendanaan internal kemungkinan tidak mencukupi, maka dari itu perusahaan juga membutuhkan dana eksternal untuk dapat membantu operasional perusahaan. Melalui tingkat pertumbuhan penjualan yang tinggi menunjukan kemampuan perusahaan menghasilan laba yang stabil. Menurut (Brigham \& Houston, 2011), perusahaan dengan penjualan yang relatif stabil dapat lebih aman memperoleh lebih banyak pinjaman dibandingkan dengan perusahaan yang penjualannya tidak stabil, karena perusahaan yang memiliki penjualan yang stabil mencerminkan aliran kas yang relatif stabil pula.Semakin tinggi tingkat pertumbuhan penjualan yang dimiliki perusahaan, maka perusahaan dapat meningkatkan kemampuannya untuk memperoleh pendapatan dan laba perusahaan. Menurut (Sayilgan, Karabacak, \& Gray, 2006) peningkatan pertumbuhan penjualan perusahaan akan berpengaruh pada peningkatan struktur modal, bagi perusahaan dengan tingkat pertumbuhan yang tinggi, kecenderungan penggunaan hutang lebih besar dibandingkan dengan perusahaan dengan tingkat pertumbuhan rendah. Artinya, perusahaan akan memerlukan dana eksternal yaitu berupa hutang untuk membiayai kegiatan operasionalnya dan membantu memenuhi biaya produksi perusahaan sehingga struktur modal perusahaan akan meningkat. Hasil penelitian yang dilakukan oleh (Serrasqueiro \& Caetano, 2014)) dan (Winahyuningsih, Sumekar, \& Prasetyo, 2011) menyatakan bahwa tingkat pertumbuhan perusahaan memiliki pengaruh yang positif dan signifikan terhadap struktur modal. Mas'ud (2008) yang menyatakan bahwa variabel growth berpengaruh positif signifikan terhadap penentuan hutang dalam struktur modal perusahaan manufaktur yang terdaftar di Bursa Efek Indonesia (BEI). Perusahaan yang tumbuh dengan pesat akan lebih banyak mengandalkan modal eksternal, karena biaya penerbitan saham biasa lebih mahal dibandingkan dengan penerbitan surat hutang. Maka, perusahaan dalam menggunakan modal eksternalnya lebih banyak mengandalkan hutang daripada equity dan hal ini sesuai dengan pecking order theory. Kazemi \& Ansari, (2012) yang menyatakan bahwa tingkat pertumbuhan (growth) positif signifikan terhadap rasio hutang. Elim dan Yusfarita (2010) menyatakan bahwa tingkat pertumbuhan penjualan (sales growth) terbukti positif signifikan terhadap struktur modal.Berdasarkan teori dan hasil penelitian empiris tersebut maka dapat dibuat hipotesis penelitian sebagai berikut.

H2 : Tingkat pertumbuhan perusahaan (growth) berpengaruh positif dan signifikan terhadap struktur modal.

\section{Pengaruh Ukuran Perusahaan (Firm Size) Terhadap Struktur Modal}

Ukuran perusahaan (Firm Size) merupakan salah satu faktor yang dipertimbangkan perusahaan dalam menentukan berapa besar kebijakan keputusan pendanaan (struktur modal) dalam memenuhi ukuran atau besarnya asset perusahaan. Ukuran Perusahaan menurut Riyanto (2010) menggambarkan besar kecilnya suatu perusahaan yang ditunjukkan dari total aktiva, jumlah penjualan, rata-rata penjualan dan rata-rata total aktiva. Ukuran besar kecilnya perusahaan ini diukur melalui logaritma natural dari total aset (Ln total aset). Total aset dijadikan sebagai indikator ukuran perusahaan karena sifatnya jangka panjang dibandingkan dengan penjualan (Titman \& Wessels, 1988) .

Jika perusahaan semakin besar maka semakin besar pula dana yang akan dikeluarkan, baik itu dari kebijakan hutang atau modal sendiri (equity) dalam mempertahankan atau mengembangkan perusahaan. Namun begitu argumen yang bisa dikemukakan disini adalah large firm akan memiliki free cash flow yang tinggi, sehingga bila memerlukan tambahan dana untuk membiayai investasi baru, maka perusahaan tersebut akan menggunakan sumber pendanaan yang murah yaitu sumber pendanaan dari dalam yang berupa retained earning. Seandainya sumber pendanaan dari dalam perusahaan, tidak mencukupi, perusahaan akan beralih pada sumber pendanaan dari luar yang berasal dari hutang daripada penerbitan saham baru. Sebaliknya pada perusahaan kecil (small firm) akan memiliki free cash flow yang rendah, sehingga sumber pendanaan dari dalam tidak bisa mencukupi tambahan dana investasi yang diperlukan, untuk itu perusahaan akan menerbitkan hutang dari pada saham baru. Hal ini dikarenakan biaya emisi saham lebih besar dari pada biaya emisi hutang dan flotation cost untuk penerbitan new equity pada perusahaan yang kecil akan lebih mahal dari pada perusahaan besar. Berdasarkan hal tersebut perusahaan yang kecil akan cenderung memilih hutang untuk membiayai investasinya, terutama berupa hutang bank (Sunarsih, 2004).Penelitian yang dilakukan Sunarsih (2004) juga (Ramlall, 2009) mendukung hipotesis ini, bahwa semakin besar ukuran perusahaan, semakin kecil jumlah proporsi hutang yang digunakan.

H2 : Ukuran perusahaan (Firm Size) berpengaruh negatif terhadap struktur modal.

Berdasarkan landasan teori serta kajian terhadap penelitian sebelumnya, maka kerangka konseptual dan hipotesis dapat digambarkan sebagai berikut:

H1: Profitabilitas (profitability) mempunyai pengaruh negatif signifikan terhadap struktur modal pada PT. Mustika Ratu dan Entitas Anak 
H2: Tingkat pertumbuhan (growth) mempunyai pengaruh positif signifikan terhadap struktur modal pada PT. Mustika Ratu dan Entitas Anak.
H3: UkuranPerusahaan (Size) mempunyai pengaruh negatif signifikan terhadap struktur modal pada PT. Mustika Ratu dan Entitas Anak

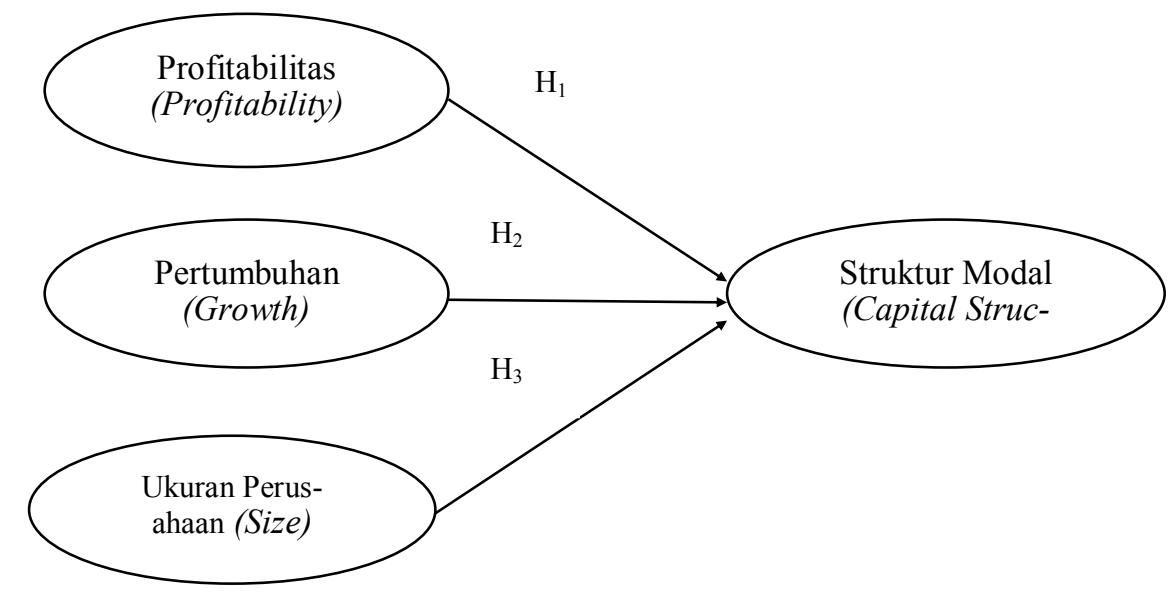

Gambar 1: Kerangka Konsep Penelitian

\section{III.METODE PENELITIAN}

Penelitian ini dilakukan untuk menganalisis hubungan dan pengaruh antara variabel profitabilitas (profitability), tingkat pertumbuhan (growth)dan ukuran perusahaan (Size) terhadap struktur modal pada PT. Mustika Ratu dan Entitas Anak periode 2012- $2016 \quad$ (PT.Mustika_Ratu, 2012) (PT.Mustika_Ratu, 2015)

\section{A. Definisi Operasional Variabel}

Variabel dalam penelitian ini terbagi menjadi variabel eksogen atau variabel bebas (independent variable) yaitu profitabilitas (profitability), tingkat pertumbuhan (growth) dan ukuran perusahaan (Size) serta variabel endogen atau variabel terikat (dependent variable) yaitu struktur modal. Variabel eksogen atau variabel bebas (independent variable) merupakan variabel yang mempengaruhi dan menjadi sebab perubahannya variabel endogen atau variabel terikat, sedangkan variabel endogen atau variabel terikat (dependent variable) merupakan variabel yang dipengaruhi atau menjadi akibat karena adanya variabel eksogen atau variabel bebas (Sugiyono, 2008).

\section{B. Variabel Eksogen atau Variabel Bebas (Independent Variable)}

\section{Profitabilitas (X1)}

Profitabilitas (profitability) dalam penelitian ini diukur dengan menggunakan rasio-rasio profitabilitas, yaitu:a) Return on Assets, ROA (X1.1) adalah pengukuran kemampuan perusahaan secara keseluruhan didalam menghasilkan keuntungan dengan jumlah keseluruhan aktiva yang tersedia didalam perusahaan. Semakin tinggi rasio ini, semakin baik keadaan suatu perusahaan (Syamsuddin, 2007:63),b) Return on Equity,ROE (X1.2) merupakan suatu pengukuran dari penghasilan (income) yang tersedia bagi para pemilik perusahaan (baik pemegang saham biasa maupun pemegang saham preferen) atas modal yang mereka investasikan didalam perusahaan. Secara umum, tentu saja semakin tinggi return atau penghasilan yang diperoleh, semakin baik kedudukan pemilik perusahaan (Syamsuddin,2007:64). c) Operating Profit margin, OPM (X1.3).Rasio ini menggambarkan apa yang biasanya disebut "pure profit" yang diterima atas setiap rupiah dari penjualan yang dilakukan. Operating profit disebut murni (pure) dalam pengertian bahwa jumlah tersebutlah yang benarbenar diperoleh dari hasil operasi perusahaan dengan mengabaikan kewajiban-kewajiban finansial berupa bunga serta kewajiban terhadap pemerintah berupa pembayaran pajak. Semakin tinggi rasio operating profit margin, akan semakin baik pula operasi suatu perusahaan (Syamsuddin, 2007:61).

Growth (X2), Tingkat pertumbuhan (growth) dalam penelitian ini diukur dengan menggunakan indikator sebagai berikut: a) Assets growth (X2.1), menggambarkan kenaikan atau penurunan aktiva setiap tahun.b) Sales growth (X2.2), menggambarkan kenaikan atau penurunan penjualan setiap tahun. Ukuran perusahaan (size), dalam studi ini ukuran Perusahaan (Size) (X3) diukur dengan indikator sebagai berikut:Ukuran (Size) $=$ Logarithm natural (Ln) of Total Assets (Ghozali, 2009) (Hermuningsih, 2012). 


\section{Variabel Endogen atau Variabel Terikat} (Dependent Variable)

Struktur Modal (Y1),Struktur modal dalam penelitian ini diukur dengan menggunakan indikator sebagai berikut: (Syamsuddin, 2007): a) Long Term Debt to Equity Ratio,LTDER (Y1.1). Rasio hutang jangka panjang terhadap modal sendiri (long term debt to equity ratio) menggambarkan struktur modal perusahaan. Rasio ini menunjukkan hubungan antara pinjaman jangka panjang yang diberikan oleh para kreditor dengan jumlah modal sendiri yang diberikan oleh pemilik perusahaan. Hal ini biasanya digunakan untuk mengukur financial leverage dari suatu perusahaan. b) Long Term Debt to Total Assets (Y1.2). Rasio ini menunjukkan hubungan antara hutang jangka panjang dengan total aktiva. Rasio ini mengukur berapa besar aktiva perusahaan yang dibiayai oleh kreditor jangka panjang.

\section{Teknik Analisis Data}

Pada fenomena bisnis, sebuah variabel tergantung dapat dipengaruhi oleh beberapa variabel bebas,juga mampu mempengaruhi variabel tergantung secara sekaligus,sehingga mengakibatkan model penelitian menjadi sangat rumit (Suliyanto, 2011), (Ferdinand, 2014) .Dalam penelitian ini analisis data menggunakan pendekatan Partial Least Square (PLS). PLS adalah model persamaan Structural Equation Modeling (SEM) yang berbasis komponen atau varian. Menurut (Ghozali, 2011) PLS merupakan pendekatan alternative yang bergeser dari pendekatan SEM berbasis kovarian menjadi berbasis varian. SEM yang berbasis kovarian umumnya menguji kualitas atau teori sedangkan PLS lebih bersifat predictive model. PLS merupakan metode analisis yang powerfull (Ghozali, 2011), karena tidak didasarkan pada banyak asumsi.Dalam PLS path modeling terdapat dua model yaitu outler model dan inner model, dimana kedua kriteria ini digunakan dalam penelitian ini.

\section{Outler Model (Measurement Model)}

Terkait dengan indikator-indikator yang membentuk variabel laten dalam penelitian ini bersifat refleksif, maka evaluasi model pengukuran (measurement model/outer model), untuk mengukur validitas dan reliabilitas indikator-indikator tersebut adalah convergent validity, discriminant validity, dan composite reliabilitya serta cronbach alpha.

\section{Inner Model (Structural Model)}

Evaluasi model struktural (Structural Model/ Inner Model) adalah pengukuran untuk mengevaluasi tingkat ketepatan model dalam penelitian secara keseluruhan, yang dibentuk melalui beberapa variabel beserta dengan indikatorindikatornya. Dalam evaluasi model struktural ini akan dilakukan melalui beberapa pendekatan diantaranya : a) R-Square (R2), b) Q-Square Predictive Relevance (Q2), dan c) Goodness of Fit (GoF).

\section{IV.HASIL DAN PEMBAHASAN}

\section{A. Hasil Penelitian}

\section{Evaluasi Outler Model}

\section{a) Convergent Validity}

Convergent Validity dari measurement model dengan indikator reflektif dapat dilihat dari korelasi antar skor indikator dengan skor konstruknya. Indikator individu dianggap valid jika memiliki nilai outler loading diatas $(>0,60)$

Tabel 1

Nilai Outer Loading Hasil Estimasi Model

\begin{tabular}{l|l|l|l|l}
\hline INDIKATOR & GROWTH & $\begin{array}{l}\text { PROFITABILI } \\
\text { TAS }\end{array}$ & SIZE & $\begin{array}{l}\text { STRUKT } \\
\text { UR }\end{array}$ \\
\hline Return On Aset,X11 & & 0,994228 & & \\
\hline Return On Equity,X12 Profit & & 0,991872 & & \\
\hline $\begin{array}{l}\text { Operating } \\
\text { Margin,X13 }\end{array}$ & & 0,977706 & & \\
\hline Aset Growth,X21 & 0,951184 & & & \\
\hline Sales Growth,X22 & 0,980910 & & & \\
\hline Ln TA, X3 & & & 1,00000 & \\
\hline LTDER,Y11 & & & & 0,997181 \\
\hline LTDAR,Y12 & & & & 0,997029 \\
\hline
\end{tabular}


Pada Tabel 1. oleh karena seluruh indikator yang merefleksikan masing-masing konstruk memiliki nilai outer loading $>0,60$ dan signifikan pada level 0,05 maka seluruh indikator adalah valid.

\section{b) Discriminant Validity}

Pengukuran validitas indikator-indikator yang membentuk variabel laten, dapat pula dilakukan melalui discriminant validity. Output discriminant validity ditunjukkan lewat hasil pengolahan data tabel berikut

Tabel 2

Uji Discriminant Validity

\begin{tabular}{l|l|l|l|l|l|l}
\hline & AVE & VAVE & GROWTH & PROFITABILITAS & SIZE & $\begin{array}{l}\text { STRUKTU } \\
\text { R MODAL }\end{array}$ \\
\hline GROWTH & 0,933468 & 0,966161 & 1.00000 & & & \\
\hline PROFITABILITAS & 0,97607 & 0,987963 & 0,71288 & 1,00000 & & \\
\hline SIZE & 1,00000 & 1,00000 & $-0,251701$ & $-0,463637$ & $\begin{array}{l}1,0000 \\
0\end{array}$ & \\
\hline $\begin{array}{l}\text { STRUKTUR } \\
\text { MODAL }\end{array}$ & 0,994218 & 0,99710 & $-0,615878$ & $-0,729349$ & $\begin{array}{l}0,8329 \\
27\end{array}$ & 1,00000 \\
\hline
\end{tabular}

Tabel 2 menunjukkan bahwa nilai AVE seluruh konstruk $>0,50$, dan rata-rata seluruh nilai Akar AVE antara 0,933468 s.d 1,0000 lebih besar dari korelasi antar konstruk yaitu antara $(0,251701$ s.d 0,832927 , sehingga memenuhi syarat valid berdasarkan criteria discriminant validity. c) Composite Reliability dan Cronbach Alpha

Suatu pengukuran dapat dikatakan reliabel, apabila composite reliability dan cronbach alpha memiliki nilai lebih besar dari 0,70 . Composite reliability dan Cronbach alpha adalah merupakan suatu pengukuran reliabilitas antar blok indikator dalam model penelitian.

Tabel 3.

Uji Composite Reliability dan Cronbach Alpha

\begin{tabular}{l|l|l}
\hline & Composite Reliability & Cronbachs Alpha \\
\hline GROWTH & 0,965582 & 0,932201 \\
\hline PROFITABILITAS & 0,991893 & 0,987744 \\
\hline SIZE & 1,00000 & 1,00000 \\
\hline STRUKTUR MODAL & 0,997101 & 0,994185 \\
\hline
\end{tabular}

Tabel 3 menunjukkan bahwa nilai composite reliability dan Cronbach Alpha seluruh konstruk telah menunjukkan nilai lebih besar dari 0.70 sehingga memenuhi syarat reliable berdasarkan criteria composite reliability.

\section{Evaluasi Inner Model}

Uji Inner Model dipergunakan untuk mengevaluasi hubungan antar konstruk laten seperti yang telah dihipotesiskan dalam penelitian. Berdasarkan output PLS, didapatkan Gambar sebagai berikut

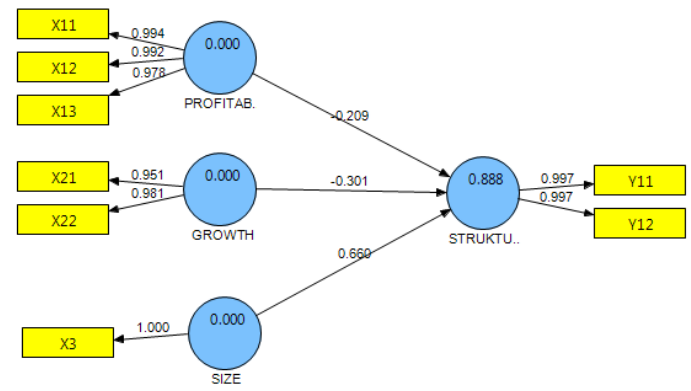

Gambar: 2

Hasil Pengolahan Model Dengan PLS 
Hasil dari Inner Weight pada gambar 2 menunjukkan bahwa Struktur Modal dipengaruhi oleh profitabilitas, pertumbuhan perusahaan (growth) dan ukuran perusahaan (size), yang kesemua ini akan djelaskan pada pengujian hipotesis.

\section{B. Pengujian Hipotesis}

Tabel 4 memberikan output estimasi untuk pengujian model struktural dimana hasil yang diharapkan adalah Ho ditolak atau nilai sig $<0,05$ (atau nilai $t$ statistic $>1,96$ untuk uji dengan level of signifikan 0,05).

Tabel 4

Path Analysis dan Pengujian Hipotesis

\begin{tabular}{|c|c|c|c|c|c|c|}
\hline & $\begin{array}{l}\text { Original } \\
\text { Sample (O) }\end{array}$ & $\begin{array}{l}\text { Sample } \\
\text { Mean } \\
\text { (M) }\end{array}$ & $\begin{array}{l}\text { Standard } \\
\text { Deviation } \\
\text { (STDEV) }\end{array}$ & $\begin{array}{l}\text { Standard } \\
\text { Error } \\
\text { (STERR) }\end{array}$ & $\begin{array}{l}\text { T Statistics } \\
(\mathrm{O} / \mathrm{STERR})\end{array}$ & Keterangan \\
\hline $\begin{array}{ll}\text { GROWTH } & > \\
\text { STRUKTUR } \\
\text { MODAL }\end{array}$ & $-0,300925$ & - & 0,014805 & 0,014805 & 20,32658 & Signifikan \\
\hline $\begin{array}{l}\text { PROFITABILITAS } \\
\rightarrow \quad \text { STRUKTUR } \\
\text { MODAL }\end{array}$ & $\begin{array}{l}- \\
0,20860009\end{array}$ & $\begin{array}{l}- \\
0,199628\end{array}$ & 0,014421 & 0,014421 & 14,465286 & Signifikan \\
\hline $\begin{array}{ll}\text { SIZE } & -> \\
\text { STRUKTUR } \\
\text { MODAL }\end{array}$ & 0,660465 & 0,663854 & 0,022095 & 0,022095 & 29,89193 & Signifikan \\
\hline
\end{tabular}

\section{Uji Hipotesis \& Pembahasan}

\section{Pengaruh profitabilitas terhadap struktur modal}

Hasil pengujian hipotesis pertama; diperoleh bahwa profitabilitas (profitability) berpengaruh negatif signifikan terhadap struktur modal pada PT. Mustika Ratu dan Entitas Anak. Hal ini ditunjukkan oleh nilai koefisien sebesar -0,20860009 dengan nilai t-statistic sebesar 14,465286 diatas nilai kritis 1,96 , sehingga hal ini menunjukkan bahwa semakin tinggi nilai profitabilitas (profitability) suatu perusahaan maka akan menurunkan nilai struktur modal perusahaan tersebut.

Hasil ini mendukung penelitian yang dilakukan oleh (Kusuma \& Arifin, 2012) yang menyatakan tingkat profitabilitas (ROA) yang tinggi memiliki struktur modal yang rendah. Ini berarti bahwa perusahaan tersebut memiliki modal sendiri yang lebih besar dibanding hutang jangka panjangnya. Hal ini disebabkan perusahaan dengan tingkat profitabilitas (profitability) yang tinggi mampu membiayai kegiatan usahanya dengan laba ditahan yang dimilikinya, sehingga perusahaan tersebut akan menggunakan hutang dalam jumlah yang relatif sedikit. Hasil ini didukung oleh Elim dan Yusfarita (2010) yang menyatakan profitabilitas (ROA) mempunyai pengaruh negatif dan signifikan terhadap struktur modal, begitu pula dengan Kazemi dan Ansari (2012) didalam penelitiannya menyatakan bahwa profitabilitas (profitability) berpengaruh negatif signifikan terhadap semua rasio hutang. Juga hasil yang didapat oleh (Septiono, Suhadak, \& Darminto, 2013) dimana profitabilitas berpengaruh negatif dan signifikan pada perusahaan Non-Bank yang terdaftar di BEI periode 20092011.Hasil ini tidak mendukung penelitian yang dilakukan oleh Kusuma (2012), profitabilitas (profitability) berpengaruh positif namun tidak signifikan terhadap struktur modal pada perusahaan real estate and property. Hal ini menunjukkan bahwa semakin tinggi nilai profitabilitas (profitability) suatu perusahaan maka akan meningkatkan nilai struktur modal perusahaan tersebut. Temuan ini juga tidak sejalan dengan hasil Mas'ud (2008) yang menyatakan bahwa terdapat hubungan positif antara profitabilitas (profitability) dengan struktur modal perusahaan

\section{Pengaruh pertumbuhan perusahaan (growth) terhadap struktur modal}

Hasil pengujian hipotesis kedua; diperoleh bahwa tingat pertumbuhan (growth) berpengaruh negatif signifikan terhadap struktur modal pada PT. Mustika Ratu dan Entitas Anak. Hal ini menunjukkan bahwa semakin tinggi pertumbuhan perusahaan maka akan menurunkan nilai struktur modal perusahaan tersebut. Hal ini ditunjukkan oleh nilai koefisien sebesar $-0,300925$ dengan nilai tstatistic sebesar 20,32658 diatas nilai kritis 1,96, sehingga hal ini menunjukkan bahwa semakin tinggi 
tingkat pertumbuhan (growth) suatu perusahaan maka akan menurunkan nilai struktur modal perusahaan tersebut. Adanya peningkatan penjualan (sales growth), perusahaan dapat meningkatkan kemampuannya untuk memperoleh pendapatan dan laba. Perusahaan dapat menutup biaya-biaya yang dikeluarkan untuk operasional perusahaan dan memperbaiki struktur modal perusahaan, karena dapat membayar hutang perusahaan dan meningkatkan modal sendiri. Temuan ini tidak mendukung hasil penelitian dari Mas'ud (2008) yang menyatakan bahwa variabel growth berpengaruh positif signifikan terhadap penentuan hutang dalam struktur modal perusahaan manufaktur yang terdaftar di Bursa Efek Indonesia (BEI). Perusahaan yang tumbuh dengan pesat akan lebih banyak mengandalkan modal eksternal, karena biaya penerbitan saham biasa lebih mahal dibandingkan dengan penerbitan surat hutang. Maka, perusahaan dalam menggunakan modal eksternalnya lebih banyak mengandalkan hutang daripada equity dan hal ini sesuai dengan pecking order theory. Hasil ini juga didukung oleh penelitian (Kazemi \& Ansari, 2012) yang menyatakan bahwa tingkat pertumbuhan (growth) positif signifikan terhadap rasio hutang. Begitu pula dengan hasil penelitian dari Elim dan Yusfarita (2010) menyatakan bahwa tingkat pertumbuhan penjualan (sales growth) terbukti positif signifikan terhadap struktur modal.Hasil ini mendukung penelitian yang dilakukan oleh Kesuma (2012) yang menyatakan bahwa arah hubungan negatif antara tingkat pertumbuhan (growth) dengan struktur modal, dimana dengan meningkatnya pertumbuhan penjualan (sales growth) akan mengurangi jumlah kewajiban dari perusahaan yang pada akhirnya struktur modal dari perusahaan juga akan berkurang. Hasil ini didukung oleh (Eriotis, Vasiliou, \& Ventoura $\square$ Neokosmidi, 2007) yang menyatakan tingkat pertumbuhan (growth) berhubungan negatif dengan financial leverage.

\section{Pengaruh ukuran perusahaan (size) terhadap struktur modal}

Hasil pengujian hipotesis ketiga ; diperoleh bahwa ukuran perusahaan (size) berpengaruh positif signifikan terhadap struktur modal pada PT. Mustika Ratu dan Entitas Anak. Hal ini menunjukkan bahwa semakin tinggi ukuran (size) suatu perusahaan maka akan meningkatkan struktur modal perusahaan tersebut. Kondisi ini ditunjukkan oleh nilai koefisien sebesar 0,660465 dengan nilai t-statistics sebesar 29,89193 (lebih besar 1,96).Hasil penelitian ini sejalan dengan temuan (Septiono et al., 2013) (Hermuningsih, 2012) yang menyatakan pengaruh ukuran perusahaan terhadap struktur modal positif signifikan. Hermuningsih menemukan ukuran perusahaan berpengaruh positif terhadap struktur modal dengan nilai signifikansi 0,012 , sedangkan Septiono (2013), variabel ukuran perusahaan berpengaruh positif signifikan terhadap struktur modal, mengandung arti bahwa dalam pengambilan keputusan yang dilakukan manajemen perusahaan terkait struktur modal yang akan digunakan oleh perusahaan, akan selalu memperhatikan peran dari ukuran perusahaan yang dalam penelitian ini menggunakan indikator tingkat penjualan dan total aktiva. Semakin besar tingkat penjualan ataupun total aktiva, maka kecenderungan penggunaan hutang jangka panjang akan semakin meningkat. Hasil ini berbeda dengan temuan Sunarsih (2004) dan Ramlall (2009) yang menemukan ukuran perusahaan berpengaruh negatif signifikan terhadap struktur modal.

\section{KESIMPULAN}

Berdasarkan hasil analisis dan pembahasan yang telah diuraikan, maka dapat diambil beberapa kesimpulan, sebagai berikut:

Variabel profitabilitas (profitability) berpengaruh negatif signifikan terhadap struktur modal pada PT. Mustika Ratu dan Entitas Anak. Hal ini ditunjukkan oleh nilai koefisien sebesar -0,20860009 dengan nilai t-statistic sebesar 14,465286 diatas nilai kritis 1,96 , sehingga hal ini menunjukkan bahwa semakin tinggi nilai profitabilitas (profitability) suatu perusahaan maka akan menurunkan nilai struktur modal perusahaan tersebut.

Variabel tingat pertumbuhan (growth) berpengaruh negatif signifikan terhadap struktur modal pada PT. Mustika Ratu dan Entitas Anak. Hal ini menunjukkan bahwa semakin tinggi pertumbuhan perusahaan maka akan menurunkan nilai struktur modal perusahaan tersebut. Hal ini ditunjukkan oleh nilai koefisien sebesar -0,300925 dengan nilai t-statistic sebesar 20,32658 diatas nilai kritis 1,96, sehingga hal ini menunjukkan bahwa semakin tinggi tingkat pertumbuhan (growth) suatu perusahaan maka akan menurunkan nilai struktur modal perusahaan tersebut

Variabel ukuran perusahaan (size) berpengaruh positif signifikan terhadap struktur modal pada PT. Mustika Ratu dan Entitas Anak. Hal ini menunjukkan bahwa semakin tinggi ukuran (size) suatu perusahaan maka akan meningkatkan struktur modal perusahaan tersebut. Kondisi ini ditunjukkan oleh nilai koefisien sebesar 0,660465 dengan nilai tstatistics sebesar 29,89193 (lebih besar 1,96)

\section{DAFTAR PUSTAKA}

Adrianto, \& Wibowo. (2007). Pengujian Teori Pecking Order pada Perusahaan- Perusahaan Non Keuangan LQ45 Periode 2001-2005. Manajemen Usahawan Indonesia, XXXVI (12), $43=53$.

Agha. (2015). Determinants of Capital Structuring 
Of Firms of Cement Sector in Pakistan. European Scientific Journal May 2015 Edition vol.11, No.13 ISSN: $1857-7881$ (Print) E - ISSN 1857- 7431, 8(1), 77-92.

Brigham, EF., and J. H. (2006). Dasar- Dasar Manajemen Keuangan (Edisi X). Jakarta: Salemba Empat.

Brigham, E. F., \& Houston, J. F. (2011). Dasar-dasar Manajemen. Keuangan. Jakarta: Salemba Empat.

Elim, \& Yusfarita. (2010). Pengaruh Struktur Aktiva, Tingkat Pertumbuhan Penjualan, dan Return On Asset Terhadap Struktur Modal Pada Perusahaan Manufaktur di Bursa Efek Jakarta. Jurnal Bisnis Dan Ekonomi, 1(1), 88103.

Eriotis, N., Vasiliou, D., \& Ventoura $\square$ Neokosmidi, Z. (2007). How firm characteristics affect capital structure: an empirical study. Managerial Finance, 33(5), 321-331. https:// doi.org/10.1108/03074350710739605

Ferdinand, A. (2014). Structural Equation Modeling Dalam Penelitian Manajemen Aplikasi Model -Model Rumit Dalam Penelitian Untuk Skripsi,Tesis dan Desertasi Doktor (5th ed.). Semarang: BP Undip Press.

Ghozali, I. (2009). Ekonometrika Teori Konsep dan Aplikasi dengan SPSS 17. Semarang: Badan Penerbi Univ Diponogoro.

Ghozali, I. (2011). Aplikasi Analisis Multivariate Dengan Program SPSS 19. (P. P.Harto, Ed.) (V). Semarang: Badan Penerbi Univ Diponogoro.

Hermuningsih, S. (2012). Pengaruh Profitabilitas,Size, Terhadap Nilai Perusahaan, Dengan Sruktur Modal Sebagai Variabel Intervening. Jurnal Siasat Bisnis, Voll6(No 2), 232-242.

Husnan, S., \& Pudjiastuti, E. (2010). Dasar- Dasar Manajemen Keuangan, Jilid I. Yogyakarta: UPP - AMP YKPN.

Karadeniz, E., Kandır, S. Y., Iskenderoglu, O., \& Onal, Y. B. (2011). Firm Size and Capital Structure Decisions: Evidence From Turkish Lodging Companies. International Journal of Economics and Financial Issues, 1(1), 1-11. Retrieved from http://www.econjournals.com/ index.php/ijefi/article/view/3

Kartini, \& Tulus, A. (2008). Struktur Kepemilikan, Profitabilitas, Pertumbuhan Aktiva dan Ukuran Perusahaan Terhadap Struktur Modal pada Perusahaan Manufaktur. Jurnal Keuangan Dan Perbankan, 12(1), Hal 11-21.

Kazemi, M., \& Ansari, Z. (2012). "The Impact of Firm Characteristics on Capital Structure of Listed Companies in Tehran Stock
Exchange". American Journal of Scientific Research. ISSN 1450-223, X(42).

Kusuma, G. I. S., \& Arifin, Z. (2012). Analisis Pengaruh Profitabilitas (profitability) Dan Tingkat Pertumbuhan (Growth) Terhadap Struktur Modal dan Nilai Perusahaan (Studi pada Perusahaan Real Estate and Property yang Terdaftar di Bursa Efek Indonesia (BEI) Periode 2007-2011). Malang.

Lumbantobing, R. (2008). Studi Mengenai Perbedaan Struktur Modal Perusahaan Penanaman Modal asing dengn Perusahaan Peneneman Modal Dalam Negeri Yang Go Public di BEI (Perspektif Teori Dasar Struktur Modal, Teori Keagenan dan Teori Kontingensi Dalam Upaya Mengoptimalkan Struktur M. Semarang.

Mai, M. (2006). Analisis Variabel-Variabel yang Mempengaruhi Struktur Modal Pada Perusahaan-Perusahaan LQ-45 di Bursa Efek Jakarta. Ekonomika, 228-245.

Mas'ud, M. (2008). Analisis Faktor-Faktor Yang Mempengaruhi Struktur Modal Dan Hubungannya Terhadap Nilai Perusahaan. Manajemen Dan Bisnis, 7(7), 69-83.

Moeldjadi. (2006). Manajemen Keuangan: Pendekatan Kuantitatif dan Kualitatif. Jilid 1. Malang: Bayumedia Publishing.

Prabansari, Y., \& Kusuma, H. (2005). Faktor Faktor Yang Mempengaruhi Struktur Modal Perusahaan Manufaktur Go Publik Di Bursa Efek Indonesia. Kajian Bisnis Dan Manajemen, 5(1), 1-15.

PT.Mustika Ratu. (2012). Laporan Tahunan $2012^{-}$,PT MUSTIKA RATU Tbk DAN ENTITAS ANAK,Laporan Keuangan Konsolidasian Untuk tahun-tahun yang berakhir 31 Desember 2012 ,http: www.mustika-ratu.co.id/annualreport/ anrep2015.pdf, diunduh 05 Mei $2017 \quad 31$ Desember 2011 dan31 Desember 2010 A. Jakarta. Retrieved from http: www.mustikaratu.co.id/annualreport/anrep2015.pdf, diunduh 05 Mei 2017

PT.Mustika_Ratu. (2015). Laporan Tahunan $2015^{-}$,PT MUSTIKA RATU Tbk DAN ENTITAS ANAK,Laporan Keuangan Konsolidasian Untuk tahun-tahun yang berakhir 31 Desember 2015 , 31 Desember 2014 dan31 Desember 2013 Annual Reporthttp: Www.mustika-ratu.co.id/ annualreport/anrep2015.pdf, diunduh. Jakarta. Retrieved from http: www.mustika-ratu.co.id/ annualreport/anrep2015.pdf, diunduh $05 \mathrm{Mei}$ 2017

Rahmatillah, I., \& Prasetyo, A. D. (2016). Determinants Of Capital Structure Analysis : 
Empirical Studi Of Telecommunication Industry In Indonesia 2008-2015, 5(3), 414 435 .

Ramlall. (2009). Determinants of Capital Structure Among Non Quoted Mauritian Firms Under Specificity of Leverage; Looking for a Modified Packing Order Theory. Journal of Finance and Economics, 1(1).

Riyanto, B. (2010). Dasar Dasar Pembelanjaan Perusahaan. Yogyakarta: BPFE.

Sartono, A. (2010). Manajemen Keuangan Teori dan Aplikasi. (A. A. Yulianto, Ed.) (Edisi 11). Yogyakarta: BPFE Yogyakarta.

Sayilgan, G., Karabacak, \& Gray. (2006). The firmspecific determinants of corporate capital structure: Evidence from Turkish panel data. Investment Management and Financial Innovations, 3(3), 125-139.

Schoubben, F., A., \& Van Hulle, C. (2004). The Determinant of Leverage: Difference between Quoted and Non Quoted Firms. Tijdschrift Voor Economie En Management, XLIX(4), 44-54.

Seftianne, \& Ratih, H. (2011). Faktor Faktor Yang Mempengaruhi Struktur Modal Pada Perusahaan Publik Sektor Manufaktur. Jurnal Bisnis Dan Akuntansi, Vol 13(No 1), Hal 3956.
Septiono, R. W., Suhadak, \& Darminto. (2013). Analisis faktor mikro terhadap struktur modal dan nilai perusahaan. Jurnal Administrasi Bisnis, 2(1), 138-151.

Serrasqueiro, Z., \& Caetano, A. (2014). Trade-Off Theory versus Pecking Order Theory: capital structure decisions in a peripheral region of Portugal. Journal of Business Economics and Management, 16(2), 445-466. https:// doi.org/10.3846/16111699.2012.744344

Suliyanto. (2011). Ekonometrika Terapan Teori \& Apalikasi Dengan SPSS. (F. S. Suyantoro, Ed.) (Ed.I). Yogyakarta: CV.ANDI OFSET.

Sunarsih. (2004). Analisis Simultanitas Kebijakan Hutang Dan Kebijakan Maturitas Hutang Serta Faktor-Faktor Yang Mempengaruhinya. Jurnal Siasat Bisnis, ISSN, 0363-7655, Vol 9 (No 1), h 65-84.

Syamsuddin, L. (2004). Manajemen Keuangan Perusahaan. Jakarta: PT Raja Grafindo Persada.

Titman, S., \& Wessels, R. (1988). The Determinants of Capital Structure Choice. Journal of Finance, Vol 43(No 1), Page 1-19.

Winahyuningsih, P., Sumekar, K., \& Prasetyo, H. (2011). Analisis Faktor-Faktor Yang Mempengaruhi Struktur Modal Pada Perusahaan Manufaktur Yang Go Public Di Bursa Efek Indonesia. 